


\title{
The role of the constitutional complaint in the legislative process: Comparative legal aspect
}

\author{
DOI: https://doi.org/10.46398/cuestpol.3969.51
}

\author{
Nataliia I. Brovko * \\ Liudmyla P. Medvid ** \\ Ihor Y. Mahnovskyi *** \\ Vusal A. Ahmadov **** \\ Maksym I. Leonenko *****
}

\begin{abstract}
The article deals with the role of constitutional complaint in the system of quality assurance of the state legislation, for protection of the rights and freedoms. Constitutional complaints, as well as their optimal models, require detailed research. Comparative analysis and survey are the main methods. The subject of a constitutional complaint in the model proposed by the authors may be laws or their individual provisions, regulations of heads of state, government, other statutes and regulations, individual administrative acts, judgements in specific cases. Citizens, foreigners, stateless persons, and legal entities are subjects who have the right to file a constitutional complaint. The authors attribute the following conditions of admissibility of a constitutional complaint: the presence and proof of violation of his/ its constitutional rights and freedoms, the use of all other remedies to protect violated rights and freedoms, compliance with deadlines for filing a constitutional complaint in some countries, and payment of state duty. The model proposed by the authors is, however, universal, and further needs to
\end{abstract} be detailed for countries of interest.

* Doctor of Law, Head of the Department, Department of Constitutional Law and Theoretical Legal Disciplines, Faculty of Law and Linguistics, Bila Tserkva National Agrarian University. ORCID ID: https://orcid.org/oooo-0003-3525-2817. Email: 091019549nb@gmail.com

** PhD in Law, Associate Professor, Department of Legal Support, Humanitarian Institute, National Defense University of Ukraine named after Ivan Cherniakhovskyi. ORCID ID: https://orcid.org/ooooooo2-0035-9748. Email: lpm176@ukr.net

*** Doctor of Law, Professor, Department of Theory and Philosophy of Law, Faculty of Training Specialists for Pre-Trial Investigation, Odessa State University of Internal Affairs. ORCID ID: https://orcid. org/oooo-ooo1-7336-6212. Email: magn.igor75@ukr.net

**** PhD in Law, Head of the Department, Research and Forensic Case Department, Academy of Justice at the Ministry of Justice Azerbaijan Republic. ORCID ID: https://orcid.org/oooo-0002-5007-4302. Email: Ahmadovvus@ukr.net

***** PhD in Law, Associate Professor, Department of Criminal, Civil and International Law, Law Faculty, Law and Management Institute, Zaporizhzhia Polytechnic National University. ORCID ID: https:// orcid.org/oooo-ooo1-8680-0612. Email: maksymzapp@gmail.com 
Nataliia I. Brovko, Liudmyla P. Medvid, Ihor Y. Mahnovskyi, Vusal A. Ahmadov y Maksym I. Leonenko

834 The role of the constitutional complaint in the legislative process: Comparative legal aspect

Keywords: constitutional complaint; constitutionaljustice; constitutional proceedings; system of legislation; constitutional court.

\section{El papel de la denuncia constitucional en el proceso legislativo: aspecto jurídico comparado}

\section{Resumen}

El artículo estudia el papel de la denuncia constitucional en el sistema de aseguramiento de la calidad de la legislación estatal, para la protección de los derechos y libertades. Las quejas constitucionales, así como sus modelos óptimos, requieren una investigación detallada. El análisis comparativo y la encuesta son los métodos principales de esta investigación. El objeto de una denuncia constitucional en el modelo propuesto por los autores pueden ser leyes o sus disposiciones individuales, reglamentos de jefes de estado, de gobierno, otros estatutos y reglamentos, actos administrativos individuales, sentencias en casos específicos. Los ciudadanos, los extranjeros, los apátridas y las personas jurídicas son sujetos que tienen derecho a presentar una denuncia constitucional. A modo de conclusión los autores atribuyen las siguientes condiciones de admisibilidad de una denuncia constitucional: la presencia y prueba de la violación de sus derechos y libertades constitucionales, el uso de todos los demás recursos para proteger los derechos y libertades violados, el cumplimiento de los plazos para la presentación de una denuncia constitucional en algunos países y pago de impuestos estatales. Sin embargo, el modelo propuesto por los autores es universal y debe detallarse más para los países de interés.

Palabras clave: denuncia constitucional; justicia constitucional; proceso constitucional; sistema legislativo; tribunal constitucional.

\section{Introduction}

Respect for human rights is the foundation of a democratic society. The institution of the constitutional complaint as one of the most important means of protection of human rights and freedoms is becoming increasingly important. Sinclair (2015: 215) rightly notes that "the existence of such a procedure largely determines the purpose of the Constitutional Court, while its absence significantly devalues constitutional justice". The idea exists in one form or another in many states in which there is a specialized judicial review of constitutionality. In analysing the types of constitutional 
complaint in the European Commission for Democracy through Law Report of January 27, 2011, which summarizes the international experience of direct access to constitutional justice, complaints of abstract and concrete review were distinguished.

The first group consists of models that determine the exercise of abstract review by the constitutional justice. Abstract review is a form of control not related to a specific case. Actio popularis provides for the possibility of a person to file a constitutional complaint on the constitutionality of a legislative act after its official promulgation in the absence of individual interest in the case, quasi actio popularis and individual proposal.

According to Petriv (2020), the second group - models of direct access to constitutional justice - are complaints, which determine the specific constitutional review associated with the consideration of a particular case - "individual complaints". In contrast to other forms of judicial protection of human rights, the specifics of the institution of constitutional complaint is manifested in the fact that the subject of appeal may be a statute or regulation, including the law, not just an individual act of law enforcement. Moreover, the constitutional review exercised in the litigation under citizens' complaints is to verify the compliance of the legal act with the Basic Law of the state, which, as Kysela (2014) notes is characterized by stability and forms the basis of national law, which allows the applicant of a constitutional complaint to challenge, among other things, (and mainly) statutes and regulations up to the level of law, relying more on the principles of law and being less dependent on the literal interpretation of the legal norm.

Concrete constitutional review involves a model of a partial constitutional complaint, which can appeal only statutes and regulations, and a model of a full complaint, which provides for the possibility of appealing statutes and regulations, as well as law enforcement acts. Aydın Çakır and Şekercioğlu (2016) distinguish two types of constitutional complaints: individual constitutional complaint (for example, in Slovakia, Slovenia). It is directly aimed at verifying the constitutionality of law enforcement acts of public authorities and indirectly - to ensure the constitutionality of law enforcement practice; mixed complaint. This type of constitutional complaint combines the features of a "public complaint" aimed at the exercise of abstract constitutional review, and "individual complaint" in order to protect the rights of a particular person (such an institution of constitutional complaint exists in Poland, Russia, Czech Republic).

Let us consider the most popular models of individual constitutional complaints. 1. Actio popularis. In Roman law, actio popularis was seen as the person's activity in the interests of society. For example, actio de positis et suspensis could be brought by any citizen against the owner of a house with any object that could cause harm to third parties; there are cases when 
Nataliia I. Brovko, Liudmyla P. Medvid, Ihor Y. Mahnovskyi, Vusal A. Ahmadov y Maksym I. Leonenko

actio popularis was used in the case of burial of the deceased in someone else's grave. In the legal literature, this action is called a civil lawsuit "in defence of everyone" (Inshyn et al., 2018).

2. Quasi actio popularis (need to prove a legitimate interest). The institution of quasi actio popularis occupies an intermediate place between abstract actio popularis and normative constitutional complaint (Albert et al., 2018). The procedure for filing quasi actio popularis requires proof of the applicant's specific legitimate interest in the application of the general norm. The difference from a normative constitutional complaint is the fact that the applicant does not necessarily have to be harmed.

3. Normative constitutional complaint. Any person has the right to file a complaint of violation of his basic subjective rights by an individual act adopted on the basis of a normative act. Normative constitutional complaint can be: a) full - in this case, each person can apply to the constitutional court to determine the constitutionality of any legal act adopted against him provided exhaustion of other possibilities to protect his rights (Ukraine, Germany, France); b) partial - a characteristic feature of this type of complaint is the limited range of objects of the constitutional complaint. This institution operates in Poland, the Russian Federation, Latvia, Armenia and some other countries (Aydın Çakır and Şekercioğlu, 2016).

Our research is based on three hypotheses:

Hypothesis 1. Full normative complaint provides a higher level of protection of the rights and freedoms of citizens compared to a partial one. To confirm the provisions of this hypothesis, we compared statistics on the constitutional complaint procedure in post-Soviet countries (Ukraine), as well as Poland, where the institution of constitutional complaint is only developing, and countries with a high level of democratic constitutional institutions (Germany), where the possibility of filing a constitutional complaint has been provided at the legislative level since 1951 .

Hypothesis 2. The level of satisfaction of constitutional complaints of citizens is much higher in developed democracies with established traditions of constitutionalism. To confirm the provisions of this hypothesis, we conducted a comparative analysis of the legislation governing the procedure for handling constitutional complaints.

Hypothesis 3. The high level of satisfaction of constitutional complaints contributes to improving the quality of the state legislation system. To confirm the hypothesis, we conducted a social online survey of citizens aged 25 to 65 - practicing lawyers, political scientists, and parliamentarians from the studied countries. 
The purpose of the research is a comparative analysis of the legal regulation of constitutional complaints in Poland, Germany, and Ukraine, aimed at identifying problems related to the choice of constitutional complaint model, and justifying possible solutions, taking into account the experience of forming and developing the constitutional complaint as the most important element of the human rights mechanism of these states.

The purpose of the study provided for the following objectives:

- defining the concept and structure of an effective model of constitutional complaint, which will help improve the quality of national legislation.

- identification of specific features of judicial proceedings on constitutional complaints in comparison with other forms of judicial protection of human rights.

- comparative legal analysis of the model of the constitutional complaint in accordance with the legislation of the studied states.

- analysis of different options for determining the range of entities authorized to file a constitutional complaint, and consideration of related issues of law enforcement activities.

\section{Literature Review}

We base our research on the belief that it is impossible to build a democratic society without a proper constitutional protection mechanism. In the substantive sense, a constitutional complaint is considered by scholars (Kosař and Vyhnánek, 2020) as a direct appeal of a private law entity to a constitutional review body with a requirement to verify the constitutionality of a legal act. According to Halmai (2018), a private law entity can be an individual and a legal entity. In some cases, local selfgovernments can also act as the subject of a constitutional complaint, but such cases are quite rare. Most scientific research, however, study appeals of individuals.

As a rule, the subject of a constitutional complaint is statutes and regulations of higher legal force after the Basic Law of the state. As Zupančič (2020) rightly noted, the process of development of constitutional review poses a number of common problems to the constitutional review bodies of young democracies, which requires mutual exchange of experience in this field. Garoupa (2020) emphasizes that all states to some extent follow a unique, self-determined way of building constitutional justice in general and the institution of constitutional complaint in particular. This is manifested primarily in the various models of organization of constitutional review in 
Nataliia I. Brovko, Liudmyla P. Medvid, Ihor Y. Mahnovskyi, Vusal A. Ahmadov y Maksym I. Leonenko

the states and the various models of constitutional complaint incorporated into national law (Navarrete and Castillo-Ortiz, 2020).

In these conditions, the comparative legal study of the institution of constitutional complaint becomes relevant, which allows exchanging experience in solving general problems of constitutional development (Bentsen et al., 2019). Given the growing importance of human rights protection, the tendency to exercise constitutional review of individual administrative acts and court judgments on the basis of individual complaints becomes apparent, because human rights violations are often the result of unconstitutional individual acts, as Bielen et al. (2018) note.

Thus, the European Commission for Democracy through Law, in its opinion on constitutional justice, concludes that human rights violations often arise through individual acts based on constitutional regulations, and the extension of the subject of a constitutional appeal to any statutes and regulations.

\section{Methods and Materials}

\subsection{Materials for Empirical Research}

We selected three countries, Ukraine, Germany, and Poland, to conduct comparative research. Let us briefly dwell on the peculiarities of the legislation on the constitutional complaint of these countries.

In June 2016, the Verkhovna Rada of Ukraine adopted the Law of Ukraine "On Amendments to the Constitution of Ukraine (Regarding Justice)", which provides for a new constitutional mechanism for protecting the rights and freedoms of citizens through the introduction of the constitutional complaint institution. Amendments to the Constitution came into force on September 30, 2016. Developing the relevant constitutional provisions, the Verkhovna Rada of Ukraine adopted a new Law of Ukraine "On the Constitutional Court of Ukraine", which establishes the procedure for filing and handling constitutional complaints, requirements for the form and content of constitutional complaints, powers of boards, senate and Grand Chamber to handle constitutional complaints, requirements for disclosure of reporting information on constitutional complaints, subjects of constitutional complaints, procedure of preliminary examination of constitutional complaint by the Secretariat of the Constitutional Court of Ukraine, list of grounds for refusal to initiate constitutional proceedings under the constitutional complaint. Certain provisions of the Law "On the Constitutional Court of Ukraine" introduced a special adviser institution (for a period up to January 1, 2020) in order to provide expert legal assistance in constitutional proceedings under a constitutional complaint. 
At the constitutional level, the procedure for the establishment and operation of the Constitutional Court of the Federal Republic of Germany is regulated in detail in the Basic Law (Article 93) and in Articles 90 and 94 the Law "On the Federal Constitutional Court of Germany" (Gesetz über das Bundesverfassungsgericht Deutschland). In Germany, there are two types of constitutional complaints that correspond to the federal system: 1) a constitutional complaint (Verfassungsbeschwerde) to the Land Constitutional Court (Verfassungsgericht) of a separate federal land, which is the basis for consideration of the violation of the constitution of this land; 2) a federal constitutional complaint filed with the Federal Constitutional Court (Bundesverfassungsgericht, FCC), which considers violations of the provisions of the Basic Law of Germany. The law governing the review by the Federal Constitutional Court of Germany is the Basic Law, or rather its provisions on the fundamental rights stipulated in Articles 1-19, and the rights equated to the fundamental (equivalent) stipulated in Articles 20.4, $33,38,101,103$ and 104. At the same time, human rights (for example, to human dignity) and the rights of a citizen (for example, to free movement across all territory of the country) do not coincide. According to this division, not only citizens of Germany have the right to appeal to the Federal Constitutional Court, but also foreign citizens - to the extent that they deny the act encroaching universal values (Kommers and Miller, 2012:12).

In the Republic of Poland, the procedure for handling constitutional complaints is established by the Constitution (Internetowy System Aktów Prawnych, 1997). In particular, Article 79 provides:

Everyone whose constitutional rights or freedoms have been violated shall have the right to file a complaint to the Constitutional Court in a case on reviewing the constitutionality of a law or other normative act underlying a final resolution on his rights, freedoms or obligations provided for in the Constitution adopted by a court or state administration body.

The Law "On the Constitutional Tribunal" (Ustawa o Trybunale Konstytucyjnym) provides:

Participants in the proceedings of the Tribunal are bodies or persons who has submitted an appeal or filed a complaint regarding a constitutional violation. A constitutional complaint (hereinafter referred to as "the complaint") may be filed after the exhaustion of all remedies provided within 3 months from the date of sending the legally effective court judgement, final decision or other final judicial act to the applicant. The court considers a complaint on the basis of the principles and in accordance with the procedural rules provided for the consideration of appeals to establish the conformity of laws and other normative acts with the Constitution (Mavčič, 2000, p. 315). 
Nataliia I. Brovko, Liudmyla P. Medvid, Ihor Y. Mahnovskyi, Vusal A. Ahmadov y Maksym I. Leonenko

The role of the constitutional complaint in the legislative process: Comparative legal aspect

\subsection{Proceeding of the Research}

The comparative study was conducted for 39 weeks using the methods of conceptual analysis, sociological analysis, comparative legal and statistical research methods. The analysis of the results was conducted at each stage in accordance with the objectives.

The study was carried out in three stages (Figure 1).

The first stage of the research involved collection and processing information about the role of the constitutional complaint in the formation of a high-quality legal system of the studied countries through specific sociological methods (analysis of expert positions, online public opinion polls). The comparative legal method allowed studying international standards and foreign experience in protecting the rights and freedoms of citizens through the constitutional complaint.

In the second stage of the study, we selected countries with different degrees of development of democratic constitutional institutions and different forms of constitutional complaints provided by law and conducted a comparative analysis of the effectiveness of impact of the chosen model of constitutional complaint on the protection of legitimate rights and interests of citizens and the quality of legislation in general. The authors chose the following countries for the comparative analysis: Germany - a country with a high level of constitutionalism and significant experience in the application of a full normative constitutional complaint, Poland - a country where the tradition of a partial normative constitutional complaint is being developed, and Ukraine, which is a synthesis of the above features (although it is a young democracy but introduces the use of a full normative constitutional complaint).

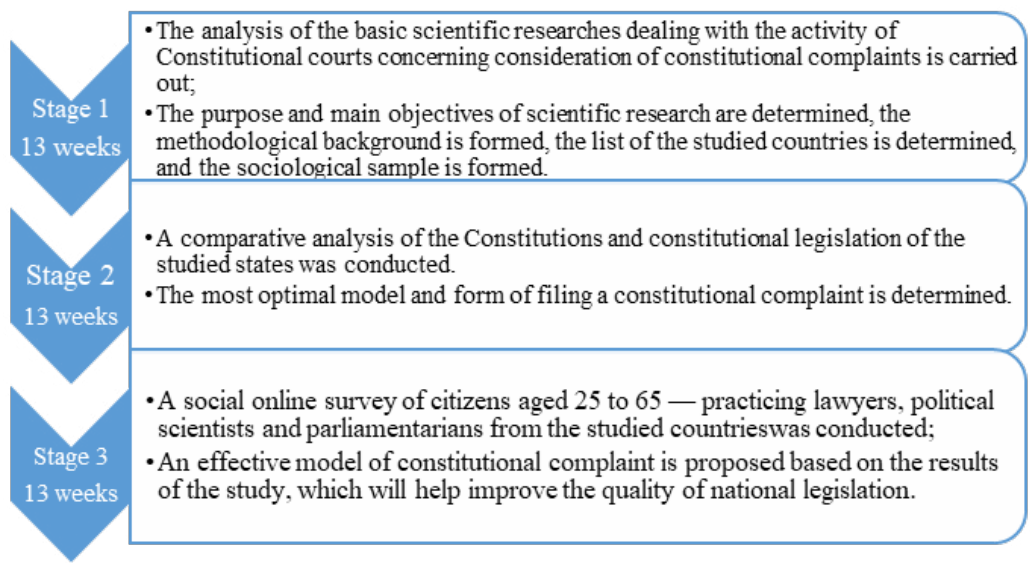

Figure 1: Stages of the study (Own creation) 


\subsection{Research Design}

The empirical background of this study is a sociological experiment conducted by the author in the third stage of research. The experiment involves 4 stages: preparatory and organizational; realization; analysis of the data obtained; registration of research results.

At the preparatory stage, we selected 200 people aged 25 to $65-$ practicing lawyers, political scientists, and parliamentarians from the studied countries. We prepared questionnaires containing 6 questions:

Do you think that the constitutional justice body of your country has a sufficient power to consider constitutional complaints?

Do you consider the process of reviewing a constitutional complaint in your country to be in line with international principles?

Have you ever had to file a constitutional complaint with the Constitutional Court?

Did your colleagues have to file a constitutional complaint with the Constitutional Court?

Do you think that the legislation regulating the procedure for considering constitutional complaints is declarative?

Do you follow the improvement of the quality of statutes and regulations after the introduction of the institution of constitutional complaint in your country?

We used STATA software to analyse the data obtained during the sociological experiment and to take into account the dynamics of the effectiveness of the constitutional complaint in the studied countries. Number of respondents $\mathrm{N}=200$, the sample size is 200 reporting units. Measurement error $7 \%$ (Table 1).

Table 1. Analysis of the effectiveness of the constitutional complaint (Own creation)

\begin{tabular}{|c|c|c|c|c|}
\hline & \multicolumn{4}{|c|}{ Years } \\
\hline Countries & 2016 & 1017 & 2018 & 2019 \\
\hline $\begin{array}{c}\text { The total number of } \\
\text { constitutional complaints filed }\end{array}$ & & & & \\
\hline Ukraine & 39 & 356 & 690 & 375 \\
\hline Germany & 5,754 & 5,982 & 5,959 & 5,446 \\
\hline
\end{tabular}


Nataliia I. Brovko, Liudmyla P. Medvid, Ihor Y. Mahnovskyi, Vusal A. Ahmadov y Maksym I. Leonenko

The role of the constitutional complaint in the legislative process: Comparative legal aspect

\begin{tabular}{|c|c|c|c|c|}
\hline Poland & 303 & 243 & 59 & 72 \\
\hline \multicolumn{5}{|c|}{$\begin{array}{l}\text { The number of rejected } \\
\text { constitutional complaints }\end{array}$} \\
\hline Ukraine & $\begin{array}{c}32 \\
(82.05 \%)\end{array}$ & $273(76.69)$ & $\begin{array}{c}426 \\
(61.74 \%)\end{array}$ & $\begin{array}{r}125 \\
(33.33 \%) \\
\end{array}$ \\
\hline Germany & $\begin{array}{c}5,729 \\
(99.57 \%)\end{array}$ & $\begin{array}{l}5,268 \\
(88.06 \%)\end{array}$ & $\begin{array}{c}5,740 \\
(96.32 \%)\end{array}$ & $\begin{array}{c}4,793 \\
(88.01 \%)\end{array}$ \\
\hline Poland & $\begin{array}{c}283 \\
(93.40 \%)\end{array}$ & $\begin{array}{l}234 \\
(96.30 \%) \\
\end{array}$ & $\begin{array}{c}29 \\
(49.15 \%) \\
\end{array}$ & $\begin{array}{c}62 \\
(86.11 \%) \\
\end{array}$ \\
\hline \multicolumn{5}{|c|}{$\begin{array}{l}\text { The number of constitutional } \\
\text { complaints on which a positive } \\
\text { decision was adopted }\end{array}$} \\
\hline Ukraine & o (o\%) & $\begin{array}{c}83 \\
(23.31 \%) \\
\end{array}$ & $\begin{array}{l}37 \\
(5.36 \%) \\
\end{array}$ & $7(1.87 \%)$ \\
\hline Germany & $\begin{array}{c}42 \\
(0.73 \%) \\
\end{array}$ & 28 (0.47\%) & $\begin{array}{c}44 \\
(0.74 \%) \\
\end{array}$ & $\begin{array}{c}26 \\
(0.48 \%) \\
\end{array}$ \\
\hline Poland & $\begin{array}{c}19 \\
(6.27 \%) \\
\end{array}$ & $9(3.70 \%)$ & $\begin{array}{c}15 \\
(25.42 \%)\end{array}$ & $\begin{array}{c}10 \\
(13.89 \%) \\
\end{array}$ \\
\hline
\end{tabular}

\section{Results}

Comparative legal analysis of the main models of constitutional complaint allows us to conclude that with the growing importance of human rights protection there is a clear tendency to exercise constitutional review over individual administrative acts and court judgements on the basis of full normative constitutional complaints, as "human rights violations are often the result of unconstitutional individual acts based on constitutional normative acts" (Mavčič, 2000: 32). The authors of this study support the institution of a full constitutional complaint not only because the remedies in the European Court of Human Rights and thriving to address human rights issues at the national level, taking into account overloaded Strasbourg court, are currently institutionally limited. A full normative constitutional complaint undoubtedly provides an opportunity for comprehensive individual access to constitutional justice and, consequently, for the full protection of individual rights. A person may appeal against any act of public authorities that directly currently violates his fundamental rights in a subsidiary manner. That is, a person may appeal a general act, if the latter is directly applicable in his case, or an individual act addressed to him. There are various grounds and forms of constitutional complaints. The main of the above is the "constitutional review", when a person "is given a remedy against the final decisions of ordinary courts, but not against individual administrative acts" (Mavčič, 2000:78). This type is 
found in Poland, Bosnia and Herzegovina, Chile and Albania. In contrast, in Austria only individual administrative acts can be considered and not final decisions in civil or criminal cases. In case of consideration of a case on the basis of a full constitutional complaint, the Constitutional Court usually does not make a decision on the merits (Ukraine, Germany). It considers constitutional issues in the case only. Besides, the Court does not review compliance with the whole hierarchy of rules (Table 2). The main function of a full constitutional complaint is to protect human rights.

Table 2. Analysis of the constitutional complaint models

\begin{tabular}{|c|c|c|c|}
\hline $\begin{array}{l}\text { Characteristics } \\
\text { of the } \\
\text { Constitutional } \\
\text { complaint }\end{array}$ & Germany & Poland & Ukraine \\
\hline $\begin{array}{l}\text { Name of the } \\
\text { constitutional } \\
\text { justice body }\end{array}$ & $\begin{array}{l}\text { Federal Constitutional } \\
\text { Court }\end{array}$ & $\begin{array}{l}\text { Constitutional } \\
\text { Tribunal }\end{array}$ & $\begin{array}{c}\text { Constitutional Court of } \\
\text { Ukraine }\end{array}$ \\
\hline $\begin{array}{l}\text { Formation } \\
\text { procedure }\end{array}$ & $\begin{array}{l}\text { Elected by the Bundestag } \\
\text { and the Bundesrat }\end{array}$ & $\begin{array}{l}\text { The Prime } \\
\text { Minister } \\
\text { approved by the } \\
\text { Seimas }\end{array}$ & $\begin{array}{l}6 \text { - selected by the } \\
\text { President } \\
6 \text { - selected by the } \\
\text { Parliament } \\
6 \text { - selected by the } \\
\text { Congress of Judges }\end{array}$ \\
\hline $\begin{array}{l}\text { Form of } \\
\text { constitutional } \\
\text { complaint }\end{array}$ & $\begin{array}{c}\text { full normative } \\
\text { constitutional complaint }\end{array}$ & $\begin{array}{l}\text { partial normative } \\
\text { constitutional } \\
\text { complaint }\end{array}$ & $\begin{array}{l}\text { full normative } \\
\text { constitutional } \\
\text { complaint }\end{array}$ \\
\hline $\begin{array}{l}\text { Subjects of } \\
\text { appeal }\end{array}$ & $\begin{array}{l}\text { Citizens of the country } \\
\text { and foreigners, legal } \\
\text { entities }\end{array}$ & $\begin{array}{l}\text { Citizens of the } \\
\text { country }\end{array}$ & $\begin{array}{l}\text { Citizens of the country } \\
\text { and foreigners, legal } \\
\text { entities, except for legal } \\
\text { entities under public } \\
\text { law }\end{array}$ \\
\hline $\begin{array}{l}\text { The subject } \\
\text { of the } \\
\text { constitutional } \\
\text { complaint }\end{array}$ & $\begin{array}{l}\text { Concerning a sentence } \\
\text { in a criminal case based } \\
\text { on a rule found to be } \\
\text { inconsistent with the } \\
\text { Basic Law or invalid } \\
\text { under Article 78, or on an } \\
\text { interpretation of a rule } \\
\text { recognized by the Federal } \\
\text { Constitutional Court to } \\
\text { be not compliant with the } \\
\text { Basic Law, it is allowed } \\
\text { to resume proceedings } \\
\text { in accordance with } \\
\text { the provisions of the } \\
\text { Criminal Procedure } \\
\text { Code. }\end{array}$ & $\begin{array}{l}\text { The decision of } \\
\text { the Constitutional } \\
\text { Tribunal on the } \\
\text { inconsistency of a } \\
\text { normative act of } \\
\text { the Constitution, } \\
\text { international } \\
\text { treaty or law which } \\
\text { was the basis for a } \\
\text { legally valid court } \\
\text { decision, final } \\
\text { administrative } \\
\text { decision or } \\
\text { decision on other } \\
\text { cases, is grounds } \\
\text { for resumption }\end{array}$ & $\begin{array}{l}\text { If non-compliance with } \\
\text { the Constitution of } \\
\text { Ukraine of other legal } \\
\text { acts (their separate } \\
\text { provisions), except } \\
\text { for those in respect } \\
\text { of which proceedings } \\
\text { are opened and which } \\
\text { influence decision- } \\
\text { making or conclusion } \\
\text { in the case, is revealed } \\
\text { in the course of } \\
\text { consideration of a case } \\
\text { on a constitutional } \\
\text { petition or } \\
\text { constitutional appeal, }\end{array}$ \\
\hline
\end{tabular}


Nataliia I. Brovko, Liudmyla P. Medvid, Ihor Y. Mahnovskyi, Vusal A. Ahmadov y Maksym I. Leonenko

844 The role of the constitutional complaint in the legislative process: Comparative legal aspect

\begin{tabular}{|c|c|c|c|}
\hline & $\begin{array}{l}\text { 2. This rule shall not } \\
\text { apply to other final } \\
\text { judgments which are } \\
\text { based on a norm which } \\
\text { has been declared invalid } \\
\text { in accordance with } \\
\text { Article 78, provided that } \\
\text { provisions of Article } \\
\text { 95(2) or special statutory } \\
\text { provisions are applied. } \\
\text { Such a decision shall } \\
\text { not be enforced. Where } \\
\text { enforcement is required } \\
\text { under the provisions } \\
\text { of the Code of Civil } \\
\text { Procedure, the provisions } \\
\text { of Article } 767 \text { shall apply } \\
\text { accordingly. Code of Civil } \\
\text { Procedure. Complaints } \\
\text { about unjust enrichment } \\
\text { are excluded. }\end{array}$ & $\begin{array}{l}\text { of proceedings or } \\
\text { for cancellation } \\
\text { of administrative } \\
\text { decision or other } \\
\text { judgement in } \\
\text { accordance with } \\
\text { the principles and } \\
\text { in the manner } \\
\text { prescribed by the } \\
\text { rules applicable in } \\
\text { this process }\end{array}$ & $\begin{array}{l}\text { the Constitutional } \\
\text { Court of Ukraine } \\
\text { declares such } \\
\text { legal acts (their } \\
\text { separate provisions) } \\
\text { unconstitutional }\end{array}$ \\
\hline Term & $\begin{array}{l}30 \text { days from the } \\
\text { moment when a person } \\
\text { learns that his right has } \\
\text { been violated }\end{array}$ & $\begin{array}{l}60 \text { days from the } \\
\text { moment when the } \\
\text { person learned } \\
\text { that his right was } \\
\text { violated }\end{array}$ & $\begin{array}{l}120 \text { days from the } \\
\text { moment when the } \\
\text { person learned that his } \\
\text { right was violated }\end{array}$ \\
\hline $\begin{array}{l}\text { Conditions for } \\
\text { accepting a } \\
\text { constitutional } \\
\text { complaint }\end{array}$ & $\begin{array}{l}\text { if a lawsuit for violation } \\
\text { is admissible, a } \\
\text { constitutional complaint } \\
\text { may be filed after all } \\
\text { remedies have been } \\
\text { exhausted }\end{array}$ & $\begin{array}{l}\text { The complaint, } \\
\text { in addition to } \\
\text { the requirements } \\
\text { for procedural } \\
\text { documents, must } \\
\text { indicate: } \\
\text { 1) a law or other } \\
\text { normative act } \\
\text { which was the } \\
\text { basis for the } \\
\text { court or other } \\
\text { public authority } \\
\text { to make a final } \\
\text { decision on the } \\
\text { rights, freedoms } \\
\text { or obligations } \\
\text { provided for in the } \\
\text { Constitution, and } \\
\text { which is denied } \\
\text { by the person who } \\
\text { filed the complaint } \\
\text { for confirmation of } \\
\text { unconstitutionality }\end{array}$ & $\begin{array}{c}\text { A constitutional } \\
\text { complaint is considered } \\
\text { admissible if it } \\
\text { meets the following } \\
\text { requirements: } \\
\text { 1) all national remedies } \\
\text { have been exhausted } \\
\text { (provided a court } \\
\text { decision adopted as } \\
\text { an appellate review of } \\
\text { judgement, which has } \\
\text { entered into force, and } \\
\text { in case of the possibility } \\
\text { provided by law for a } \\
\text { cassation appeal - a } \\
\text { court decision rendered } \\
\text { in a cassation review); } \\
\text { 2) from the date of } \\
\text { entry into force of the } \\
\text { final court decision } \\
\text { in which the law of } \\
\text { Ukraine (its separate } \\
\text { provisions) is applied, } \\
\text { if no more than three } \\
\text { months have elapsed. }\end{array}$ \\
\hline
\end{tabular}

We used STATA software to analyze the data obtained during the sociological experiment and take into account the dynamics of the effectiveness of the constitutional complaint in the studied countries (Table 3). 
Table 3. The results of sociological surveys conducted by the author

\begin{tabular}{|c|c|c|c|}
\hline \multirow{2}{*}{ Questions and answer options } & \multicolumn{3}{|c|}{ Countries } \\
\cline { 2 - 4 } & Germany & Poland & Ukraine \\
\hline $\begin{array}{c}\text { Do you think that the constitutional justice body } \\
\text { of your country has a sufficient power to consider } \\
\text { constitutional complaints? }\end{array}$ & & & \\
\hline Yes & $75 \%$ & $42 \%$ & $31 \%$ \\
\hline No & $25 \%$ & $58 \%$ & $69 \%$ \\
\hline $\begin{array}{c}\text { Do you consider the process of reviewing a } \\
\text { constitutional complaint in your country to be in } \\
\text { line with international principles? }\end{array}$ & & & \\
\hline Yes & $57 \%$ & $48 \%$ & $34 \%$ \\
\hline No & $43 \%$ & $52 \%$ & $66 \%$ \\
\hline Yes & & & \\
\hline $\begin{array}{c}\text { Have you ever had to file a constitutional } \\
\text { complaint with the Constitutional Court? }\end{array}$ & $14 \%$ & & \\
\hline No & $86 \%$ & $100 \%$ & $100 \%$ \\
\hline Yes & & \\
\hline $\begin{array}{c}\text { Did your colleagues have to file a constitutional } \\
\text { complaint with the Constitutional Court? }\end{array}$ & & & \\
\hline No & $10 \%$ & & \\
\hline Yes & $90 \%$ & $100 \%$ & $100 \%$ \\
\hline $\begin{array}{c}\text { Do you think that the legislation regulating } \\
\text { the procedure for considering constitutional } \\
\text { complaints is declarative? }\end{array}$ & & & \\
\hline Yes & $12 \%$ & $75 \%$ & $82 \%$ \\
\hline No & $88 \%$ & $25 \%$ & $18 \%$ \\
\hline $\begin{array}{c}\text { Do you follow the improvement of the quality of } \\
\text { statutes and regulations after the introduction } \\
\text { of the institution of constitutional complaint in } \\
\text { your country? }\end{array}$ & & & \\
\hline No & $24 \%$ & $67 \%$ & $70 \%$ \\
\hline
\end{tabular}

According to opinion polls, experts have not recognized the effectiveness of the constitutional complaint model of any country. However, the support of certain elements of the proposed models allows forming a single effective model of constitutional complaint that effectively affects the quality of the legal system of individual countries (Figure 2). 
Nataliia I. Brovko, Liudmyla P. Medvid, Ihor Y. Mahnovskyi, Vusal A. Ahmadov y Maksym I.

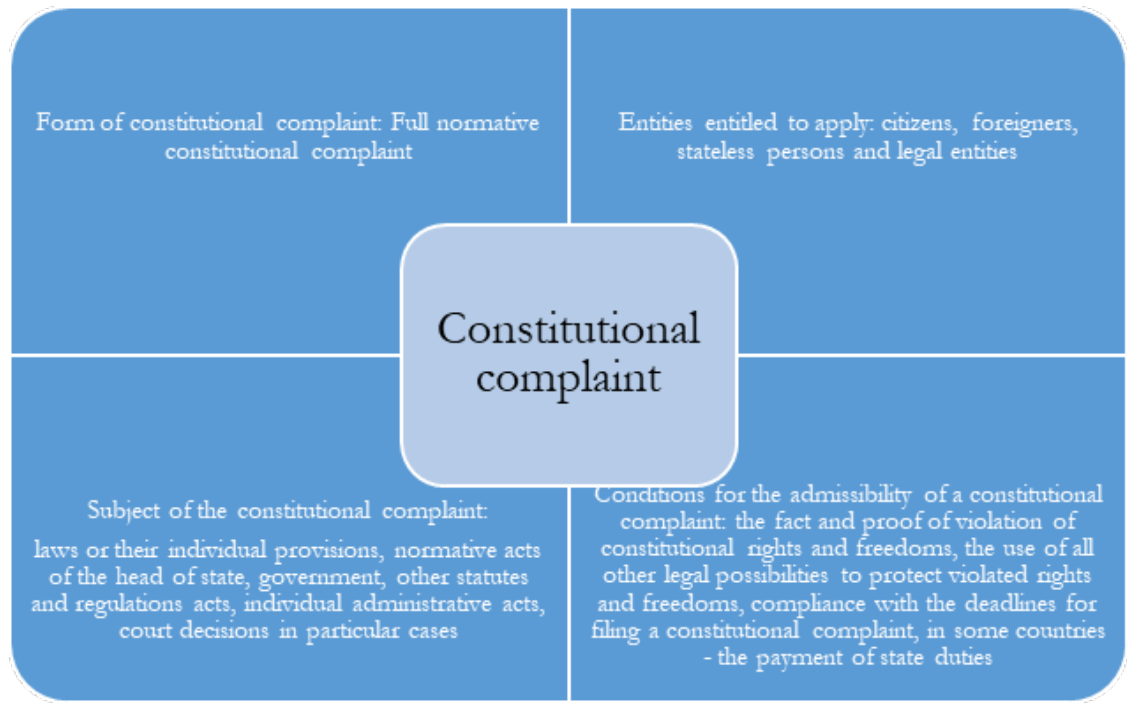

Figure 2: Constitutional complaint consideration model

\section{Discussion}

The debate on the role and importance of a constitutional complaint in improving the quality of legislation in international scientific circles has been going on for a long time, with many supporters and many critics (González-Ocantos, 2016). Bricker and Wondreys (2018) support the position that anyone can file a complaint against a normative act after its promulgation, without being obliged to prove that the relevant norm directly and currently affects his rights and freedoms. Lübbe-Wolff (2016) also defined the actio popularis as the main guarantee of comprehensive constitutional review, since anyone can apply to the Constitutional Court. In this case, the citizen simply fulfills his duty to protect the Constitution. It is not necessary that the applicant's fundamental rights be violated. According to the case of Goldstein v. Sec'y Commonwealth, actio popularis plays a minor role in Liechtenstein (where several conditions must be met for actio popularis), Malta, Peru and Chile, while it promotes law and order in Hungary and Georgia (Casetext, 2020; Pellegrina et al., 2017). In South Africa, a party to justice may go to court in the public interest. However, Wendel et al. (2020) exclude actio popularis from the number of effective solutions, because abuse is inevitable in this case. In Croatia, the actio popularis has led to an overload of the Constitutional Court, a problem that the Venice Commission is also critical of. 
An individual proposal is a type of abstract control initiated by a natural or legal person and leaves much room for judgment to the Constitutional Court (Reutter, 2020). In this case, a natural or legal person may apply to the Constitutional Court with a proposal to consider the constitutionality of a normative act, but it may not demand consideration of the case. He also notes that the dismissal of review must be motivated. A natural or legal person may file "a complaint against the violation of his basic subjective rights by an individual act adopted on the basis of a normative act. In this case, the initiative to exercise review is related to a specific case" (Meyer, 2020:483).

However, an "individual act applying a normative act cannot be challenged, and the review exercised by the Constitutional Court does not concern the application of a normative act" (Meyer, 2020:480). In support of its position Meyer (2020) notes that there is a regulatory complaint in Armenia, Belgium, Georgia, Hungary, Kyrgyzstan, Latvia, and Monaco, among others.

The restricted form has been introduced in Estonia, where some decisions of the Parliament and the President can be appealed. According to Article 96 of the Federal Constitutional Law of the Russian Federation "On the Constitutional Court", citizens "whose rights and freedoms are violated by the law applicable in a particular case" may apply directly to the Constitutional Court. An individual complaint may be filed directly with the Constitutional Court and referred to an administrative decision.

It should be noted that an individual complaint differs from an abstract review, as the applicant must prove that there is a certain probability that the law is applicable in his case. According to Pildes (2020), the effectiveness of a normative constitutional complaint as a means of protecting human rights depends more on the decisions of ordinary courts that apply the decisions of the Constitutional Court, especially when there is no mandatory legal requirement for ordinary courts to comply with the Constitutional Court. When ordinary courts do not take into account the legal positions expressed in the decisions of the Constitutional Court, and formally satisfy only their final part, the normative constitutional complaint becomes an end in itself and an ineffective means of protecting the constitutional rights of the person concerned. Decisions of the Constitutional Court are sources of constitutional law that give a final interpretation of constitutional provisions, and all public authorities, including ordinary courts, must abide by them (Sadurski, 2015).

In countries where there is a specialized Constitutional Court, an individual complaint to this Court is a logical choice as such a remedy, since the complaint is also, as a rule, subsidiary at the national level and is applied only after exhaustion of remedies in ordinary courts at the last possible stage at the national level, until there is an opportunity to appeal to the European Court of Human Rights. 
Nataliia I. Brovko, Liudmyla P. Medvid, Ihor Y. Mahnovskyi, Vusal A. Ahmadov y Maksym I. Leonenko

848 The role of the constitutional complaint in the legislative process: Comparative legal aspect

It is obvious that some other types of individual access to the Constitutional Court covered in this study cannot be considered in this sense as an effective "domestic remedy": for example, actio popularis aims at the norm from an abstract point of view and usually cannot be an appropriate remedy against certain violations of human rights (Rezende Oliveira, 2020). "Normative" individual complaint is aimed only at the normative act and not at its application in a particular case. It is an appropriate national "filter", as in practice violation of human rights is often not the result of "technically correct" application of unconstitutional law. A large number of human rights violations thus do not fall within the scope of the normative complaint, and the effectiveness of this institution becomes insignificant.

\section{Conclusions}

Summing up the above, we note that the results of our sociological, empirical and comparative studies, as well as world experience show that it is impossible to systemically ensure the supremacy of the Constitution and ensure sustainable development of constitutionalism without the introduction of an effective institution of full (rather than partial) constitutional complaint. On the basis of analytical and statistical research, we can say that the most effective form of human rights protection is the consideration of a constitutional complaint directly in the Constitutional Court without intermediaries (courts of general jurisdiction, for example). Based on the results of the study, we propose an effective model of a constitutional complaint: a full normative constitutional complaint.

Subject of the constitutional complaint: laws or their separate provisions, normative acts of the head of state, government, other statutes and regulations, individual administrative acts, court decisions in particular cases. Subjects that have the right of appeal: citizens, foreigners, stateless persons, and legal entities. Conditions for the admissibility of a constitutional complaint: the fact and proof of violation of constitutional rights and freedoms, the use of all other legal possibilities to protect violated rights and freedoms, compliance with deadlines for filing a constitutional complaint in some countries, as well as payment of state duty.

\section{Bibliographic References}

ALBERT, Richard; LANDAU, David; FARAGUNA, Pietro; DRUGDA, Šimon. (Eds.). 2018. "Global Review of Constitutional Law." Available Online. In: https://poseidono1.ssrn.com/delivery.php?ID=720026113081005 10712602012609109610201901406901708803602208410911802111 00720710261000251000290230380191070871151051110300280870 
42047011052015001031066005001030092067055085127089124004 020111117121118003127076082022029007007079107115002093 029067028081\&EXT=pdf\&INDEX=TRUE. Date of consultation: 20/12/2020.

AYDIN ÇAKIR, Aylin; ŞEKERCIOĞLU, Eser. 2016. "Public confidence in the judiciary: the interaction between political awareness and level of democracy” In: Democratization. Vol. 23, No. 4, pp. 634-656.

BENTSEN, Henrik Litleré; MCKENZIE, Mark Jonathan.; SKIPLE, Jon Kåre. 2019. "Confronting SKAT in the Højesteret: An investigation into how EU law, precedent, litigant resources, and structural reform shape tax decisions" In: UCHP Fiscal Relations Law Journal. Vol. 1, No. 1, pp. 1-30.

BIELEN, Samantha; PEETERS, Ludo; MARNEFFE, Wim; VEREECK, Lode. 2018. "Backlogs and litigation rates: Testing congestion equilibrium across European judiciaries" In: International Review of Law and Economics. Vol. 53, pp. 9-22.

BRICKER, Benjamin; WONDREYS, Jakub. 2018. "Public opinion and opposition party success: Evidence from the European constitutional courts" Justice System Journal. Vol. 39, pp. 123-138.

CASETEXT. 2020. Goldstein v. Sec'y Commonwealth. Available online. In: https://casetext.com/case/goldstein-v-secy-commonwealth Date of consultation: $20 / 12 / 2020$.

GAROUPA, Nuno. 2020. "Constitutional Courts in Civil-Law Western Europe: Quantitative Approaches. George Mason Law \& Economics. Research paper No. 20-05." Available online. In: https://poseidono1.ssrn.com/ delivery.php?ID=048098119110097000073004028098101 095019007 0640590480871120951050941260740811230940861200620440060 0609606212609812509503109311005908509008908806612011102 010107608908605101310111212609601109512111809609300412500 $8126004001118126104126110067121085089006 \& \mathrm{EXT}=\mathrm{pdf} \&$ INDEX=TRUE. Date of consultation: 20/12/2020.

GONZÁLEZ-OCANTOS, Ezequiel. 2016. "Evaluations of human rights trials and trust in judicial institutions: Evidence from Fujimori's trial in Peru" In: The International Journal of Human Rights. Vol. 20, No. 4, pp. 445470 .

HALMAI, Gábor. 2018. "Abuse of constitutional identity. The Hungarian Constitutional Court on interpretation of Article E) (2) of the fundamental law" In: Review of Central and East European Law. Vol. 43, No. 1, pp. 23-42. 
Nataliia I. Brovko, Liudmyla P. Medvid, Ihor Y. Mahnovskyi, Vusal A. Ahmadov y Maksym I. Leonenko

850 The role of the constitutional complaint in the legislative process: Comparative legal aspect

INSHYN, Mykola; MIROSHNYCHENKO, Yurii; PAIDA, Yurii. 2018. "Protection of constitutional cultural rights and freedoms of citizens by the constitutional court of Ukraine" In: Baltic Journal of Economic Studies. Vol. 4, No. 4, pp, 134-139.

INTERNETOWY SYSTEM AKTÓW PRAWNYCH. 1997. The Constitution Of The Republic Of Poland Of April 2, 1997, Adopted By The National Assembly On April 2, 1997, Adopted By The Nation In A Constitutional Referendum On May 25, 1997, Signed By The President Of The Republic Of Poland On July 16, 1997. Available online. In: http://isap.sejm.gov.pl/ isap.nsf/home.xsp Date of consultation: 20/12/2020.

KOMMERS, Donald P.; MILLER, Russell A. 2012. "The Constitutional Jurisprudence of the Federal Republic of Germany" 3rd edition, revised and expanded." Duke University Press, Durham, UK.

KOSAŘ, D.; VYHNÁNEK, L. 2020. Constitutional identity in the Czech Republic. In C. Calliess; G. van der Shyff (eds.), "Constitutional Identity in a Europe of Multilevel Constitutionalism". Cambridge University Press. Cambridge, UK.

KYSELA, Joseph. 2014. The Influence of the Constitutional Court on the Rules of Legislative Process in the Czech Republic. Charles University in Prague, Faculty of Law, Research Paper No. 2014/II/4/. Available online. In: https://ssrn.com/abstract=2540565. Date of consultation: 20/12/2020.

LÜBBE-WOLFF, Gertrude. 2016. Constitutional courts and democracy. Facets of an ambivalent relationship. In: Klaus Meßerschmidt; A. Daniel OliverLalana (eds.), "Rational Lawmaking under Review". Springer, Cham.

MAVČIČ, Arne. 2000. Constitutional Court Act With Explanations, (Nomos Collection). Nova revija. Ljubljana, Slovenia.

MEYER, Philipp. 2020. "Judicial public relations: Determinants of press release publication by constitutional courts" In: Politics. Vol. 40, No. 4, pp. 477-493.

NAVARRETE, Rosa M.; CASTILLO-ORTIZ, Pablo. 2020. "Constitutional courts and citizens' perceptions of judicial systems in Europe” In: Comparative European Politics. Vol. 18, pp, 128-150.

PELLEGRINA, Lucia Dalla.; GAROUPA, Nuno; GÓMEZ-POMAR, Fernando. 2017. "Estimating judicial ideal points in the Spanish supreme court: The case of administrative review" In: International Review of Law and Economics. Vol. 52, pp. 16-28. 
PETRIV, Ivan Mykhaylovych. 2020. "Practical aspects of the implementation by the Constitutional Court of Ukraine of functional powers in the mechanism of state authority" In: Scientific Papers of the Legislation Institute of the Verkhovna Rada of Ukraine. Vol. 4, pp. 129-139.

PILDES, Richard H. 2020, June 17. The Constitutional Emergency Powers of Federal Courts. Available online. In: https://ssrn.com/ abstract $=3629356$. Date of consultation: $20 / 12 / 2020$.

REUTTER,Werner.2020.SubnationalConstitutionalCourtsandJudicialization in Germany. Available online. In: https://doi.org/10.1057/s41304-02000293-8. Date of consultation: 20/12/2020.

REZENDE OLIVEIRA, Mariana. 2020. "Constitutional courts in transitions to democracy: Limits, critiques and possibilities in Brazil and Argentina" In: Latin American Law Review. Vol. 5, pp. 27-44.

SADURSKI, Wojciech. 2015. Constitutional courts and legislation. In: "Rights Before Courts" Springer, Cham.

SINCLAIR, Barbara. 2015. Can Congress be trusted with the Constitution? The effects of incentives and procedures. In: Neil Devins; Keith E. Whittington (eds.), "Congress and the Constitution". Duke University Press. Durham, UK.

WENDEL, M., REESTMAN, J. H., CLAES, M. 2020. "Better in than out: When constitutional courts rely on the charter" In: European Constitutional Law Review. Vol. 16, No. 1, pp. 1-7.

ZUPANČIČ, Boštjan M. 2020. "Constitutional law and the jurisprudence of the European Court of Human Rights: An attempt at a synthesis” In: Revus. Vol. 1, pp. 57-61. 

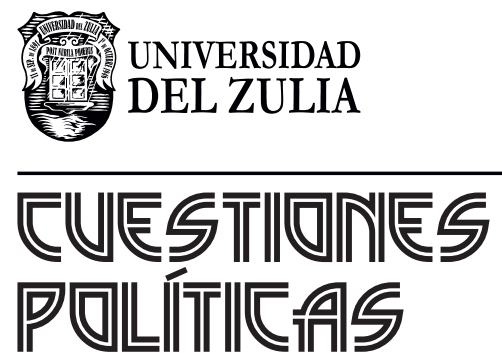

Vol.39 No 69

Esta revista fue editada en formato digital y publicada en julio de 2021, por el Fondo Editorial Serbiluz, Universidad del Zulia. Maracaibo-Venezuela 